\title{
Heavy Metals in Water, Sediments and Macrophytes in the Shkodra Lake
}

\author{
Erdona Demiraj $*^{1}$, Jamarbër Malltezi ${ }^{2}$, Seit Shallari ${ }^{3}$ and Sulejman Sulçe ${ }^{4}$
}

\begin{abstract}
Concentrations of some heavy metals in water, sediment and macrophytes of the Shkodra Lake were investigated in two periods (July - September) of 2012 in seven different sampling sites. The concentrations of the metals were determined using ICP. $\mathrm{Cu}, \mathrm{Fe}, \mathrm{Ni}, \mathrm{Mn}, \mathrm{Pb}$ and $\mathrm{Zn}$ were detected in all the sampling stations in water, sediments, and macrophytes. Average data indicated the $\mathrm{Cu}$ concentration was under $0.4 \mu \mathrm{g} \mathrm{L}-1$ in water, $33 \mathrm{mg} \mathrm{kg}-1$ on sediments, and $14.9 \mathrm{mg} \mathrm{kg}-1$ in macrophytes. The Fe values in water were low in September and very high in July. The highest values were observed in sediments (up to $15 \mathrm{~g} \mathrm{~kg}$-1), which were consistent with values found in water macrophytes. The water values for $\mathrm{Mn}$ were up to $0,058 \mathrm{mg} \mathrm{L}-1$, in sediments up to $729 \mathrm{mg} \mathrm{kg}-1$, while the average concentration in macrophytes was $436 \mathrm{mg} \mathrm{kg}-1$. The highest values of $\mathrm{Ni}$ in water were observed in July $(0.262 \mathrm{mg} \mathrm{L}-1)$, in sediments was $216 \mathrm{mg} \mathrm{kg}-1$ and the highest values of the three $(\mathrm{Cu}$, $\mathrm{Ni}, \mathrm{Zn}$ ) elements observed in water macrophytes. The data obtained for $\mathrm{Pb}$ were mainly in sediments, with the average value at $23.5 \mathrm{mg}$ $\mathrm{kg}-1$. For all sampling stations the content of $\mathrm{Zn}$ in water were lower than $0.2 \mu \mathrm{g} \mathrm{L}-1$. Its average value in sediment was $35.4 \pm 23.35 \mathrm{mg}$ $\mathrm{kg}-1$. The average macrophyte values of $\mathrm{Cu}(14.9 \pm 13.4 \mathrm{mg} \mathrm{kg}-1)$, $\mathrm{Ni}(68 \pm 68 \mathrm{mg} \mathrm{kg}-1)$ and $\mathrm{Zn}(30 \pm 14.3 \mathrm{mg} \mathrm{kg}-1)$ were comparable to the corresponding values found in sediments for all stations and periods.
\end{abstract}

Keywords-Shkodra Lake, water, sediments, macrophyte, heavy metals.

\section{INTRODUCTION}

The problems of metal pollution is currently increasing in Shkodra Lake. It is mainly associated with intensification of agricultural activities and the lack of urban and industrial water discharge infrastructure. Under some environmental conditions, those pollutants including metals could accumulate and get biomagnified through food chain to toxic levels [1]. When heavy metals enter in water bodies, they change water quality, bind to sediments and accumulate in aquatic biota causing anemia, disturbance of physiological functions and mortalities of fish [2].

Erdona Demiraj ${ }^{1}$, PhD Candidate, Department of Agro-Environment and Ecology, Agriculture University of Tirana, 1029 Tirana, Albania' corresponding author's phone: + 355695299 447; e-mail: erdonad@ hotmail.com

${ }^{2}$ Department of Agro-Environment and Ecology, Agriculture University of Tirana, 1029 Tirana, Albania; e-mail: abi.malltezi@gmail.com

${ }^{3}$ Department of Agro-Environment and Ecology, Agriculture University of Tirana, 1029 Tirana, Albania; e-mail: seitshallari@gmail.com

${ }^{4}$ Department of Agro-Environment and Ecology, Agriculture University of Tirana, 1029 Tirana, Albania; e-mail: sulejmansulce@yahoo.com
Heavy metals also pose a serious threat to humans through ingestion of metal enriched aquatic organisms. Main anthropogenic sources of heavy metal contamination are mining, disposal of untreated and partially treated effluents contain toxic metals, as well as metal chelates from different industries and indiscriminate use of heavy metal-containing fertilizer and pesticides in agricultural fields [3], [4], [5]. At low levels in water, some elements like, $\mathrm{Pb}\left(0.10 \mathrm{mgL}^{-1}\right)$ [6] and $\mathrm{Cu}\left(0.05 \mathrm{mgL}^{-1}\right)$ pose threats to humans [2]. However, at high concentrations, these trace metals become also toxic [7].

The purpose of this study was to evaluate the concentrations of different selected metals $(\mathrm{Pb}, \mathrm{Zn}, \mathrm{Cu}, \mathrm{Mn}$, $\mathrm{Fe}$ and $\mathrm{Ni}$ ) in different components such as water, sediments and three main type of macrophyte present in Shkodra Lake.

\section{STUDY SITE}

The Shkodra/Skadar Lake is the largest shallow lake in southeastern Europe. It is a Managed Nature Reserve, included in the Ramsar List of international important wetlands, so its preservation and protection from pollution is very important. However, intensive industrial and urban development in the region have exposed the lake to anthropogenic pollution by organic and inorganic contaminants, including metals [5].

The largest contributors to the lake with regard to various pollutants are the rivers and creeks that pass through urban and rural settlements, and the last ones transport pollution from agricultural activity down to the lake. Previous studies have demonstrated that lake sediments are contaminated by metals, mostly $\mathrm{Ni}$ and $\mathrm{Cr}$ [5], [6].

\section{MATERIALS AND METHODS}

\section{A. Selection of sampling stations}

The survey was carried out in two different period June and September 2012. The sampling stations was determined based on the geomorphology of the study area, tributary location, general hydrology, point and non - point source pollution identified. Based on the potential exposure of the lake to different source of agro-industrial and other source of pollutants, seven representative sampling sites: (Site-1 (S1): Bajçe, Site-2 (S2) Stërbeq, Site-3 (S3) Vraka, Site-4 (S4) Lumi Buna, Site-5 (S5) Bahçallëk, Site-6 (S6) Shirokë and Site-7 (S7) Zogaj : reference site by MoE) were selected (Figure1). The following criteria were applied in selection of sampling stations: (i) Sensitivity of the area, (ii) A review of existing data, (iii) Areas where rivers flows into the Lake, (iv) Known sources of pollution (point and non - point source pollution), (vi) The influence of tributaries and hydrological modifications. 


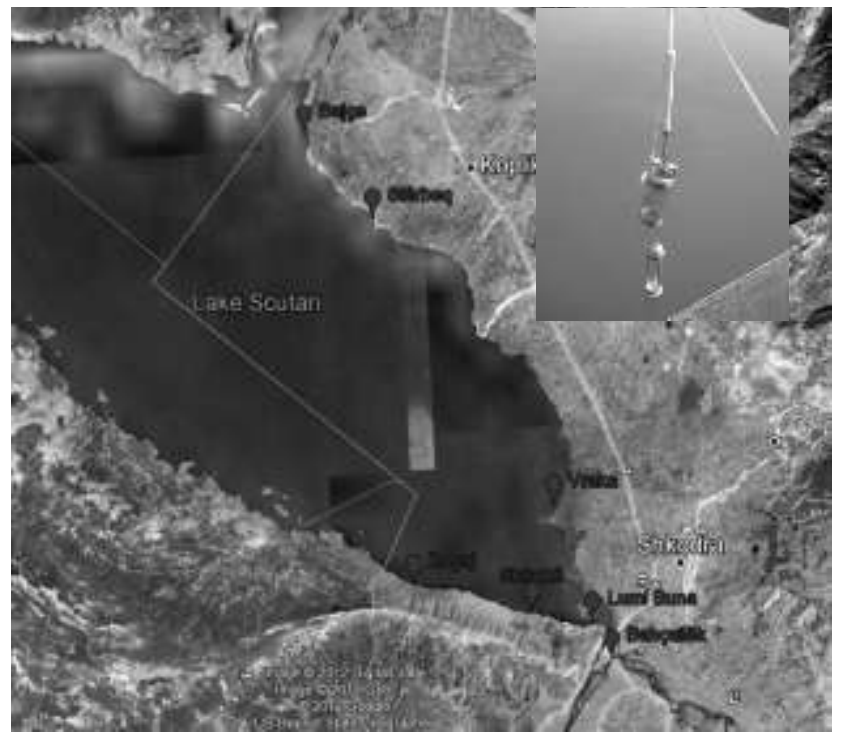

Fig. 1. Maps Location sampling stations for water, sediments and mycrophytes. Water sampling procedure with Ruttner.

TABLE I. THE LOCATION Of THE SAMPLE STATION AND THEIR COORDINATE In Universal TransVERSE MERCATOR SySTEM (UTM).

\begin{tabular}{llll}
\hline Nr. & $\begin{array}{l}\text { Location } \\
\text { name }\end{array}$ & $\begin{array}{l}\text { Coordinate } \\
\text { X }\end{array}$ & Coorddinate $\mathbf{Y}$ \\
\hline S1 & Bajçe & 364443.00 & 4676376.00 \\
S2 & Stërbeq & 366938.00 & 4672993.00 \\
S3 & Vraka & 373337.00 & 4661609.00 \\
S4 & Lumi Buna & 374559.00 & 4657035.00 \\
S5 & Bahçallëk & 375237.00 & 4655591.00 \\
S6 & Shirokë & 372179.00 & 4657590.00 \\
S7 & Zogaj & 367591.00 & 4658987.00 \\
\hline
\end{tabular}

\section{B. Water samples analytical method}

Sampling of water was carried out in accordance with standard ISO - 5667-1. Preservation, handling transport and storage of water samples will be in accordance with standard ISO-5667-3. The water sampling were made in two levels: top (5 cm under water surface) and deep (30 cm under water surface) using a "Ruttner" sampler figure 2. All the samples will send to the laboratory in a portable fridge at $4^{\circ} \mathrm{C}$.

Water samples were collected in $150 \mathrm{~mL}$ bottles from each station and for $25 \mathrm{~mL}$ of each sample were treated with $6 \mathrm{~mL}$ of $68 \% \mathrm{v} / \mathrm{v} \mathrm{HNO} 3$ before analysis. The concentrations of the metals were determined using inductively coupled plasma optic emission spectroscopy (ICP OES DV-Perkin Elmer) after microwave digestion based on EPA 3015a were $45 \mathrm{~mL}$ from sample was added nitric acid $\left(\mathrm{HNO}_{3}\right)$ and hydrochloric acid $(\mathrm{HCl})$.

\section{Sediment samples analytical method}

Sediment samples used for heavy metal fractions analysis were taken by a "Van Veen" grab sampler at the bottom of water in each sample stations in September, which were quickly packed in air tight polythene bags. Samples for analysis of heavy metals were dried, crushed and passed through $1 \mathrm{~mm}$ sieve in the laboratory before analysis based on EPA 3050b. For each digestion procedure, we have weigh to the nearest $0.01 \mathrm{~g}$ and transfer a $1 \mathrm{~g}$ sample (dry weight) to a digestion vessel and add $10 \mathrm{~mL}$ of $1: 1 \mathrm{HNO}_{3}$. Heat the sample at $95^{\circ} \mathrm{C} \pm 5^{\circ} \mathrm{C}$ and reflux for 10 to 15 minutes without boiling. The samples was cooled, and add $5 \mathrm{~mL}$ of concentrated $\mathrm{HNO}_{3}$ and $3 \mathrm{~mL}$ of $30 \% \mathrm{H}_{2} \mathrm{O}_{2}$. After cooling, the samples was diluted to $100 \mathrm{~mL}$ with distilled water and then measured on Inductively Coupled Plasma Mass Spectrometry (ICP-MS).

\section{Plant samples analytical method}

At each sampling site, the aquatic plant samples of different macrophytes as Potamogeton crispus, Potamogeton perfoliatus and Trapa natans were collected in September for each sample station, at a constant depth of $40 \mathrm{~cm}$. Each sample consisted of a pool of 2-3 plants, which were washed in the lake before being placed in polyethylene bags and taken to the laboratory in coolers.

Once there, the plants were rinsed again with distilled water to remove any material adhering to their surfaces. From samples of the dried plant material was weight $(1 \mathrm{~g} \pm 0.05)$ plant tissue and insert into a glazed porcelain crucible and into a cool muffle furnace for 2 hour. After that was digested using a mixture of $10 \mathrm{ml} \mathrm{HCl} \mathrm{(1:1)}$ and concentrated $3 \mathrm{ml} \mathrm{HNO}_{3}$ (1:1) and in the end the sample after cool was transferred to $50 \mathrm{ml}$ volumetric flask with distilled water [8]. Finally, the contents of $\mathrm{Cu}, \mathrm{Fe}, \mathrm{Mn}, \mathrm{Ni}, \mathrm{Pb}$ and $\mathrm{Zn}$ were analyzed using inductively coupled plasma optic emission spectroscopy (ICP OES DV-Perkin Elmer).

\section{RESULTS AND DISCUSSIONS}

A. Heavy metals in water

Distributions of $\mathrm{Cu}, \mathrm{Fe}, \mathrm{Mn}, \mathrm{Ni}, \mathrm{Pb}$ and $\mathrm{Zn}$ concentrations at seven water samples for two investigated period are presented in Fig. 2 Fig. 3. 


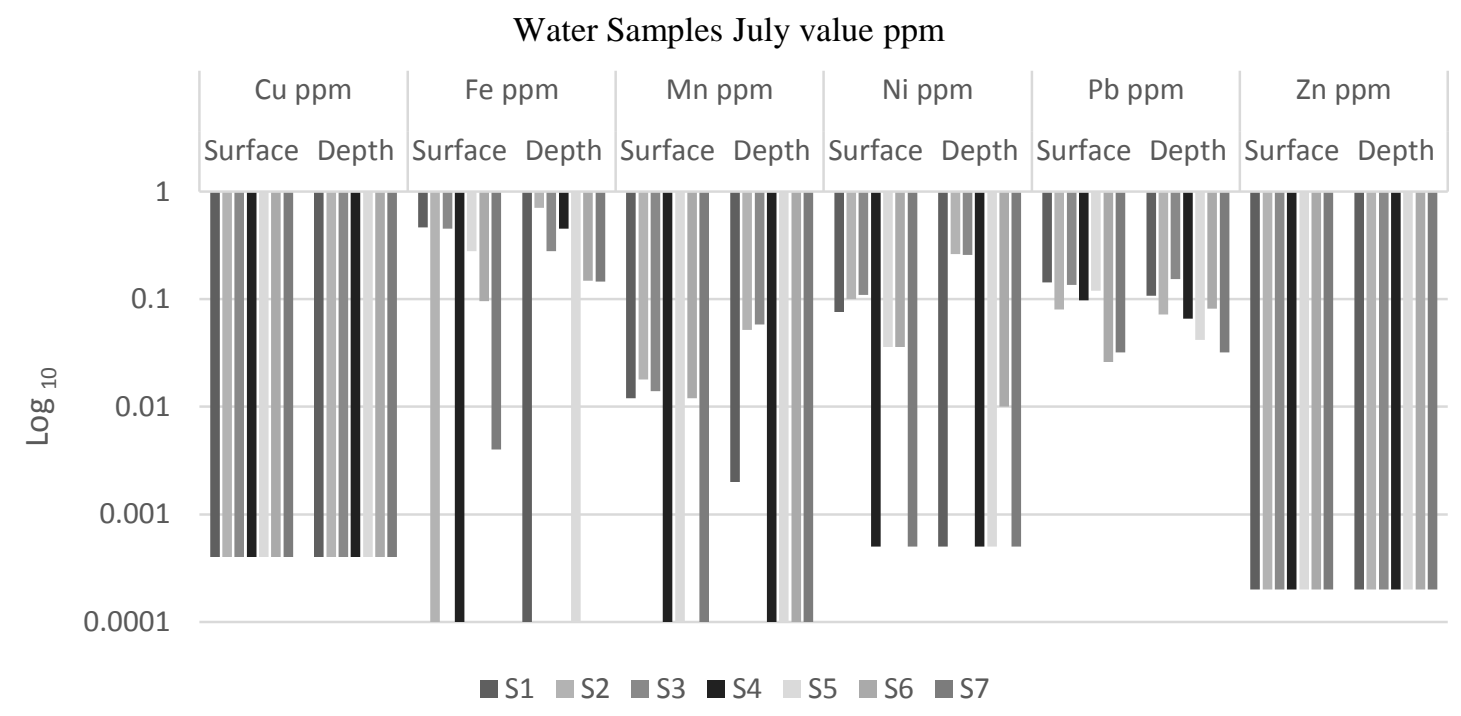

Fig. 2. Heavy metals concentration found in July measured in $\mathrm{mgL}^{-1}$ or ppm expressed in Logarithmic Scale base 10 .
B. Copper-Cu
D. Manganese $-\mathrm{Mn}$

As we found, the $\mathrm{Cu}$ content is $<0.4 \mu \mathrm{gL}^{-1}$ in all cases (including the seasons and measuring stations) or the same as the limit detection value. In such conditions, the Lake does not have a significant amount of $\mathrm{Cu}$, even at station 5 where due to the copper-containing minerals of Drini watershed, values of this metal were expected.

\section{C. $\quad$ Iron $-\mathrm{Fe}$}

For September, the Fe values in water were low, smaller than $0.1 \mu \mathrm{g} \mathrm{L}^{-1}$ or lower than the limit detection expect for three stations, at the bottom, where the highest value does not exceed $0.05 \mathrm{mgL}^{-1}$. In July, the values vary from 0.05 (station 5) to $0.708 \mathrm{mgL}^{-1}$ that was the highest value found.
Mn values are low. In most of the cases in September, they are under the detection limit $\left(<0.1 \mu \mathrm{gL}^{-1}\right)$, except for stations 3 and 4 with values varying from 0.002 to $0.006 \mathrm{mgL}^{-1} \mathrm{Mn}$. In July, they vary from 0.002 (station 1) to $0,058 \mathrm{mgL}^{-1}$ (station $3)$.

\section{E. Nickel-Ni}

$\mathrm{Ni}$ values in water were low; in our measurements they were lower than the limit detection $\left(\leq 0.5 \mu \mathrm{g} \mathrm{L}{ }^{-1}\right)$. The highest values were in July, for station 2 and 3, with 0.262 and 0.258 $\mathrm{mgL}^{-1}$, respectively. Values in the other stations varied from 0.008 to $0.056 \mathrm{mgL}^{-1}$.

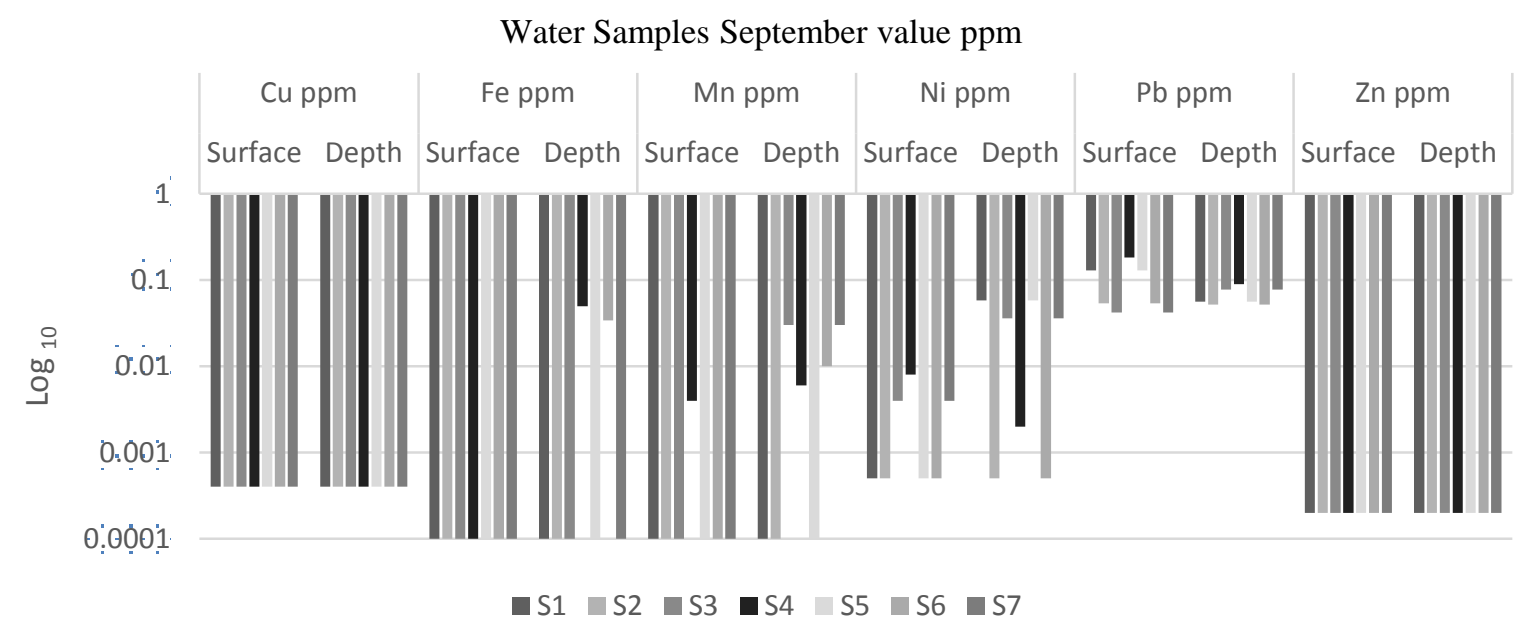

Fig. 3. Heavy metals concentration found in September measured in $\mathrm{mgL}^{-1}$ or ppm expressed in Logarithmic scale base 10 . 


\section{F. $\quad$ Lead $-\mathrm{Pb}$}

In Fig. 2 and Fig. 3 we can see, the $\mathrm{Pb}$ values in the water for two seasons, in seven sampling stations in-depth and surface, as average values. Values found in July $(0.096 \pm 0.03)$ are higher than in September $(0.079 \pm 0.041)$ except Fig. 4 for stations 4 and 7 . Their variation between surface and bottom is more visible in July (two times higher in the surface compared to the bottom). Minimum and maximum values were 0.032 (station 7) up to $0.144 \mathrm{mgL}^{-1} \mathrm{~Pb}$ (stations 1 and 3 ). The European standard for $\mathrm{Pb}$ content in water is $\leq 7.2 \mathrm{mgL}^{-1}$, EPA-USA $\leq 50 \mathrm{mgL}^{-1} \mathrm{~Pb}$, GB $3838-200 \leq 5.0 \mathrm{mg} \mathrm{L}^{-1}$ and $\mathrm{WHO} \leq 50 \mathrm{mgL}^{-1}$ and the values found in Lake's water are $<$ $0.15 \mathrm{mg} \mathrm{Pb} \mathrm{L}^{-1}$.

\section{G. Zinc - Zn}

For all the values found in the study (including season and station) the content of $\mathrm{Zn}$ in water was $<0.2 \mu \mathrm{g} \mathrm{Zn} \mathrm{L}{ }^{-1}$, lower than the detection limit.

\section{HeAvy Metals In SEDIMENTS}

The pollution of sediments is of natural and anthropogenic origin. Erosion and leaching of phosphate rock in the surrounding areas have an important contribution [9]. In

Fig. 5 shows the content of the four heavy metals contained in the sediment.

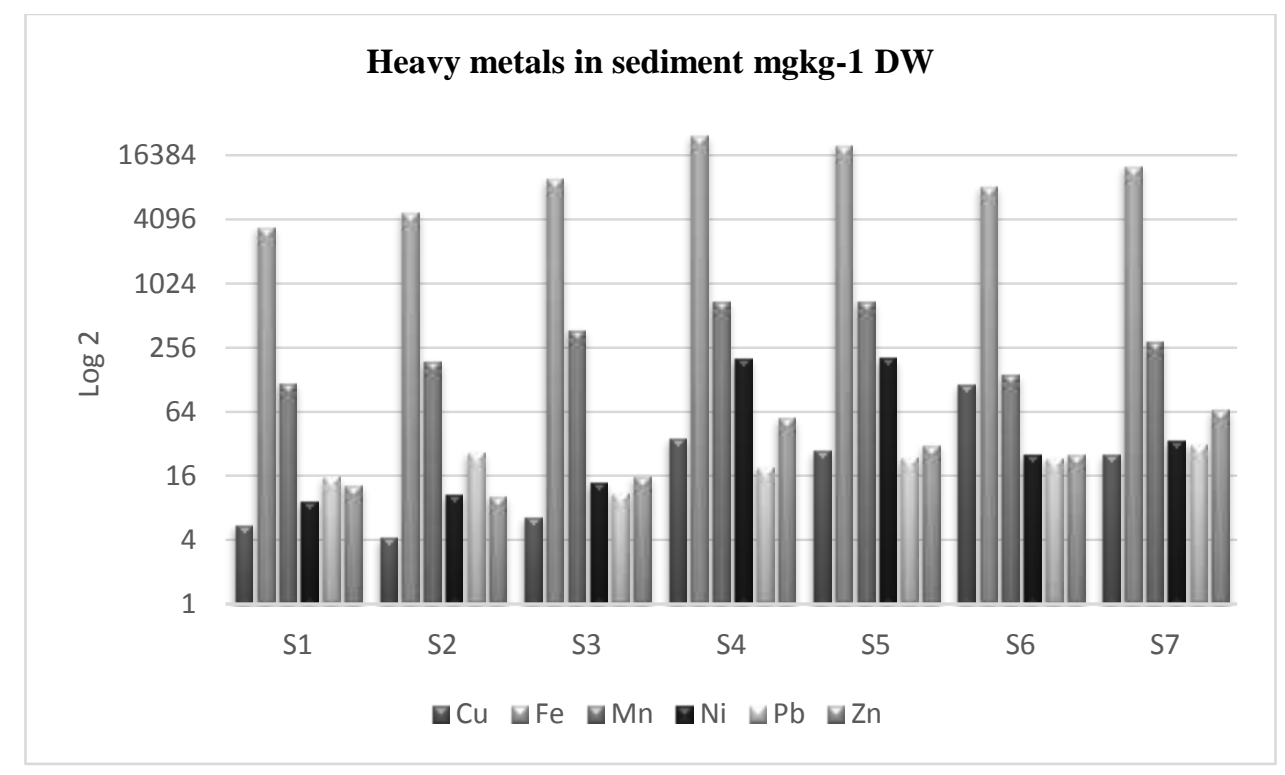

Fig. 5. The content of $\mathrm{Cu}, \mathrm{Fe}, \mathrm{Mn}, \mathrm{Ni}, \mathrm{Pb}$ and $\mathrm{Zn}$ in the sediment in $\mathrm{mgkg}^{-1}$ dry weight (DW).

$\mathrm{Cu}$ content in the sediment is on average $33 \pm 37 \mathrm{mgkg}^{-1}$ with a minimum of $4.31 \mathrm{~S} 2$ and maximum $117.72 \mathrm{mgkg}^{-1} \mathrm{~S} 6$, both on the shallow coasts (eastern and Shiroka). The average value of $\mathrm{Ni}$ for the seven stations was $91 \pm 99.9 \mathrm{mgkg}^{-1}$ and the minimum and maximum values were 9.4 and $210.77 \mathrm{mgkg}^{-1}$, respectively in $\mathrm{S} 1$ and $\mathrm{S} 5$. The average value of $\mathrm{Pb}$ was $23.5 \pm 7.9 \mathrm{mgkg}^{-1}$ and with variations up to three times between the maximum $\left(32.19 \mathrm{mgkg}^{-1}\right)$ and minimum $\left(11.1 \mathrm{mgkg}^{-1}\right)$ value, with the maximum value found at the $S 7$.

$\mathrm{Zn}$ varies from 10.5 to $69 \mathrm{mgkg}^{-1}$ with the highest content found in S7. Its average value was $35.4 \pm 23.35 \mathrm{mgkg}^{-1}$. For $\mathrm{Cu}$ and especially for $\mathrm{Ni}$, there are higher variations compared to the other two metals ( $\mathrm{Pb}$ and $\mathrm{Zn}$ ). To assess the negative effects we have considered the guidelines of National Oceanographic and Atmospheric Administration (NOAAUSA) [10] for the biological effects of heavy metal content in the sediment, where ERL is the Effect Range Low and ERM Effect Range Medium [11].

TABLE II: ERL and ERM values according to heavy metals guidelines in $\mathrm{mgkg}^{-1}$, dry weight (DW) and percentages of incidence for the biological effects in the range of concentration defined for both values.

In ERL for $\mathrm{Cu}$, categorized as the limit where biological effects start to appear, is 35 while the average found was 33 $\mathrm{mgkg}^{-1}$. In $\mathrm{S} 6$ the value of $\mathrm{Cu}$ were 40 and were within the range of the biological effects of this concentration (34-270 $\mathrm{mgkg}^{-1} \mathrm{Cu}$ ).

For $\mathrm{Ni}$, ERL and ERM values are 21 and $52 \mathrm{mgkg}^{-1}$, respectively while the average content of $\mathrm{Ni}$ is $23 \mathrm{mg} \mathrm{kg}$ and values for stations S4, S5, S6 and S7 were > or >> than 21 $\mathrm{mgkg}^{-1}$ (207 and $210 \mathrm{mgkg}^{-1}$ for S4 and S5). In the last stations (S4 and S5) Ni concentrations threaten the biota with values exceeding the accepted range as ERM $\left(52 \mathrm{mgkg}^{-1}\right)$.

For $\mathrm{Pb}$, the average value $\left(23.5 \mathrm{mgkg}^{-1}\right)$ was significantly higher than ERL for this metal (8.0) but lower than ERM (217 $\mathrm{mgkg}^{-1}$ ). In stations S2 and S7 the ERL value is significantly exceeded which means that the biological effects are felt. The average value for $\mathrm{Zn}$ was $35 \mathrm{mgkg}^{-1}$ and the maximum value $69 \mathrm{mgkg}^{-1}$ or much lower than the ERL value for this metal, 
which means that there are no biological effects caused by this metal. The average value of $\mathrm{Fe}$ was about $14 \mathrm{mgkg}^{-1}$ of dry sediment with a standard deviation $\left( \pm 9114 \mathrm{mgkg}^{-1}\right.$ while the variability is higher. The maximum value was 26807 and the minimum only $3538 \mathrm{mgkg}^{-1}$, or 8 times less. The highest values were found on stations S4 and S5 (>15 $\mathrm{gkg}^{-1}$ sediment). Mn values compared to $\mathrm{Fe}$ were much lower; the average value was $405 \pm 269 \mathrm{mgkg}^{-1}$ with a maximum and minimum 729 and $120 \mathrm{mgkg}^{-1}$, respectively. As for Fe, stations S4 and S5 where characterized by high concentrations of $\mathrm{Mn}$

\section{HEAVy METALS In MacrophyteS}

Macrophytes are considered as important component of the aquatic ecosystem since they serve as food source for aquatic invertebrates and can act as efficient accumulator of heavy metals [12].

Distribution of metals in aquatic macrophytes depends primarily on the macrophytes species, plant organs and the type of metal [13]. Fe and $\mathrm{Mn}$ are considered as major elements for the plant physiology and metabolism.

Moreover, at a lower level also $\mathrm{Cu}, \mathrm{Zn}$ and $\mathrm{Ni}$ are important for the process of photosynthesis and are considered as essential microelements in macrophytes. On differing, $\mathrm{Pb}$ is a toxic element and inhibitory to the metabolic processes; in large concentrations in plants it may pass to the food chain from water products to humans.

The average values of $\mathrm{Fe}$ in macrophytes were high $\left(11363 \pm 6337 \mathrm{mgkg}^{-1}\right)$ dry matter plant tissues with maximum and minimum values 18768 and 4306, respectively. The highest values were found in stations 4 and 5. Compared to the content of this metal in sediments, content levels in plant tissues were lower.

$$
\text { Heavy metals in Plants mgkg }{ }^{-1}
$$

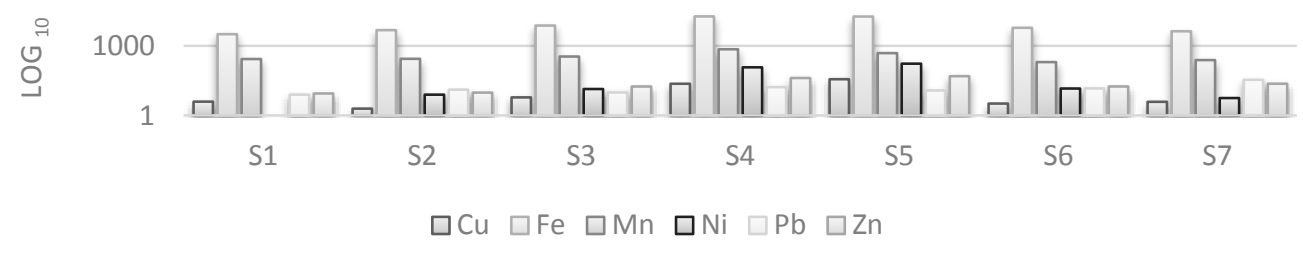

Fig. 6. The content of $\mathrm{Cu}, \mathrm{Fe}, \mathrm{Mn}, \mathrm{Ni}, \mathrm{Pb}$ and $\mathrm{Zn}$ in different macrophytes ( $\mathrm{mgkg}^{-1}$ Dry Mater).

The average content of Mn in plants was $436 \pm 205 \mathrm{mg} \mathrm{kg-}{ }^{1}$ with a variation of maximum and minimum values, 721 and 202 , respectively. Values found in macrophytes are almost similar with those found in sediments. The average values of $\mathrm{Cu}\left(14.9 \pm 13.4 \mathrm{mgkg}^{-1}\right), \mathrm{Ni}\left(68 \pm 68 \mathrm{mgkg}^{-1}\right)$ and $\mathrm{Zn}(30 \pm 14.3$ $\mathrm{mgkg}^{-1}$ ) were comparable to the corresponding values found in sediment. The highest values of the three elements correspond to stations 4,5 and 8 , all located along Buna river flow. The average value of $\mathrm{Pb}$ was $17.95 \pm 8.36$ or a little bit lower than the average content value in sediment $\left(23.5 \mathrm{mgkg}^{-1}\right)$ and the station with the highest concentration was station 7 (Zogaj). Heavy metals accumulate more in sediments than in aquatic organisms and water [2], [14], [15] and as such sediments act as sinks and sources of supply of heavy metals to overlying water columns. In view of the fact

\section{REFERENCES}

[1] Amare TA, Yimer GT, Workagegn KB , "Assessment of Metals Concentration in Water, Sediment and Macrophyte Plant Collected from Lake Hawassa, Ethiopia," J Environ Anal Toxicol , vol. 5, no. 1, p. 247, 2014.

[2] G. Post, "Textbook of fish health.," in T.F.H. New Jersey: Publication Inc., 1983 , pp. $45-56$.

[3] Amman AA, Michalke B, Schramel P., "Speciation of heavy metals in environmental water by ion chromatography coupled to ICP-MS.," Analytical Biochemistry, vol. 372, no. 3, pp. 448-452, 2002.

[4] V. Hatje, E. D. Bidone, and J. L., Maddock, "Estimation of the natural and anthropogenic components of heavy metal fluxes in fresh that heavy metals such as $\mathrm{Pb}$, and $\mathrm{Zn}$ are good markers of contamination from human activity detection of these metals in Shkodra Lake indicates contamination of the lake's water by human activities.

Data obtained indicated that the heavy metals were accumulating more in sediments than in aquatic organisms and water column, hence the sediments act as sinks and sources of heavy metals to overlying water.

Amare TA, Yimer GT, Workagegn KB , "Assessment of Metals Concentration in Water, Sediment and Macrophyte Plant Collected from Lake Hawassa, Ethiopia," J Environ Anal Toxicol, vol. 5, no. 1, p. 247, 2014.

water Sinos river, Rio Grande do Sulstate, South Brazil.," Environ. Tech, vol. 19, no. 5, pp. 483-487, 1998.

[5] J. Nouri, A. H. Mahvi, G. R. Jahed, and A. A., Babaei, "Regional distribution pattern of groundwater heavy metals resulting from agricultural activities.," Environ. Geo., vol. 55, no. 6, pp. 1337-1343, 2008.

[6] ISI, "Indian standard tolerance limits for island surface water subject to pollution, 2 revision," Indian standard institute, 22961982.

[7] Bruce T. N., Darko G. Akoto O., "Heavy metals pollution profiles in streams serving the Owabi reservoir.," African Journal of Environmental Science and Technology, vol. 2, no. 11, pp. 354-359., 2008.

[8] LLC Taylor \& Francis Group, Reference Methods for Plant Analysis, , Yash P. Kalra, Ed. Boca Raton, Boston, London,New York, 
Washington, D.C.: CRC Press, 1998.

[9] Cheng S., "Heavy metals in plants and phytoremediation.," Environ Sci \& Pollut Res, vol. 10, no. 5, pp. 335-340., 2003.

[10] 1995 NOAA-USA, "Sediment quality Guidelines developed for National status and Trends program.," 1995.

[11] ER and MacDonald, Long, "National Status and Trends Program approach. In: Sediment classification methods compendium.," Washington, DC: U.S., EPA 823-R-92-006, 1992.

[12] M. Alikaj and F. Brahushi, "Heavy Metals Assessment in the Macrophytes of Viroi Lake.," Albanian j. agric. sci. , pp. 245-252, 2017.

[13] P. Guilizzoni, "The role of heavy metals and toxic materials in the physiological ecology of submersed macrophytes.," Aquatic Botany, vol. 41, pp. 87 - 109, 1991.

[14] J. Tariq, M. Ashraf, M. Jaffar and M. Afzal, "Pollution status of the Indus River, through heavy metal and macronutrient contents of fish,sediment and water.," Water Reserch, vol. 30, no. 6, pp. 1337 1344, 1996.

[15] M. Ravanelli, O. Tubertini, S. Valcher and W. Martinotti, "Heavy metal distribution in sediment cores from western Ross sea(Antartica).," Water, Air and Soil pollution., vol. 99, pp. 697 704, 1997.

[16] Stešević, D., Feiler, U., Sundić, D., Mijović, S., Erdinger, L., Seiler, T. B., Heininger, P., Hollert, H., "Application of a new sediment contact test with Myriophyllum aquaticum and of the aquatic Lemna test to assess the sediment quality of Lake Skadar.," Journal of Soils and Sediments, vol. 7, pp. 342-349, 2007.

[17] Vemić, M., Rousseau, D., Du Laing, G., Lens, P., "Distribution and fate of metals in the Montenegrin part of Lake Skadar.," vol. 29, pp. $357-367,2014$ 